\title{
Democracy and New Media: Capturing Masculinity in Online News About Election Selfie
}

\section{Demokrasi dan Media Baru: Memotret Maskulinitas dalam Pemberitaan Online Tentang Selfie Pemilu}

\author{
Monika Sri Yuliarti \\ Universitas Sebelas Maret, J1. Ir. Sutami 36A Surakarta \\ e-mail: monika.yuliarti@staff.uns.ac.id
}

\begin{abstract}
Election selfie has been a quite phenomenon since the 2014 election in Indonesia. In the last election, 2019, there was a famous actor, Nicholas Saputra, who posted his inked finger selfie in his Instagram account as one of his campaign efforts for the youth to be involved in the election, and surprisingly, it became a bombshell in the online world. This study examined the representation of masculinity in the online new relates to the election selfie by Nicholas Saputra. This research involved five (5) online news articles from a reputable online news portal in Indonesia using a critical discourse analysis perspective that was adopted from the Sara Mills model. It was found that traditional masculinity was represented in research objects, which were the strengths and the practical way of life. Moreover, it was also found that in terms of subjectobject position, there was no balance in the opportunity to speak between the subject and object. Finally, as to the writer-reader position, the writer also held a more significant privilege to decide the position of the reader.
\end{abstract}

Keywords: Election Selfie; Instagram; Masculinity; Sara Mills

\begin{abstract}
Abstrak
Selfie Pemilu telah menjadi fenomena yang cukup populer sejak pemilihan umum tahun 2014 di Indonesia. Pada pemilihan umum terbaru, 2019, ada seorang aktor terkenal, Nicholas Saputra, yang mengunggah foto selfie dengan jari bertinta di akun Instagram-nya sebagai salah satu upaya kampanyenya bagi kaum muda untuk terlibat dalam pemilihan, dan yang mengejutkan, itu menjadi hal yang sangat besar dalam dunia online. Penelitian ini berupaya untuk meneliti representasi maskulinitas dalam media online yang berkaitan dengan selfie pemilu oleh Nicholas Saputra. Penelitian ini melibatkan lima (5) artikel berita online dari portal berita online terkemuka di Indonesia, dan menggunakan perspektif analisis wacana kritis yang diadopsi dari model Sara Mills. Ditemukan bahwa maskulinitas tradisional terwakili dalam objek penelitian, yaitu kekuatan dan praktis. Selain itu, juga ditemukan bahwa dalam hal posisi subjekobjek, tidak ada keseimbangan dalam hal kesempatan untuk berbicara antara subjek dan objek. Lebih lanjut, dalam hal posisi penulis-pembaca, penulis, dalam hal ini media juga memiliki hak istimewa yang lebih besar untuk memutuskan bagaimana posisi pembaca.
\end{abstract}

Kata Kunci: Instagram; Maskulinitas; Sara Mills; Selfie Pemilu 


\section{Introduction}

Indonesia is a democratic country that has held elections for several times. The significant changes had happened in the 2004 election since it was the first direct Presidential Election, where the public could elect the president and vice president directly. It was carried out by the People's Consultative Assembly (KPU RI, n.d.), and Susilo Bambang Yudhoyono and Jusuf Kalla were the first elected president and vice president, which was resulted from direct Presidential Elections by Indonesian citizens.

Meanwhile, the emergence of internet technology that has been initiated since 1962 by J.C.R. Licklider through the concept of "Galactic Network" (Barry et al., 2015) provided a change in every aspect of human's life, including in democratic practice. We Are Social, a research agency based in the UK, reported that in early 2018, more than 4 billion of the total population were internet users with 53\% penetration (Kemp, 2018). In early 2017, only half of the population were internet users (Kemp, 2017), while back in 2016 , the internet penetrated only $46 \%$ of the population (Kemp, 2016). All three data indicate that there was a significant increase in the number of internet users around the world.

This trend also occurred in Indonesia. There was also a rise, although only a slight one. Based on the Association of Indonesian Internet Service Provider, in 2016, 51.8\% of the total population were internet users ( 132.7 million). There was a rise in the number of Indonesian people who became internet users in two years before. It is reported that 252.4 million of the total population were internet users, which means that only $34.9 \%$ (APJII $\&$ Polling-Indonesia, 2016). In addition, in the following year, 2017, the survey found that $54.8 \%$ of the total population of Indonesia were internet users, which went up at about $3 \%$ compared to the data in 2016 (Teknopreneur, 2017).

The establishment of new media as a result of information and communication technology, namely the internet, leads to a new form of the communication process. The invention of printing technology began the new era of the communication field. Later on, internet technology gives a significant improvement in the communication field, with the emergence of new media.

The easiest way to understand what new media is can be done by drafting a list of terms that often appear regarding new media, such as internet, e-mails, online news site, social media, social networking sites, web sites, blogs, and so forth. Based on the list, it can be understood that generally people define new media as the use of a computer for distribution and exhibition rather than production (Manovich, 2006).

Although new media is a new field in communication study, many studies have been done regarding this topic, such as the utilization of new media in various areas of life (Olutola, Olatoye, \& Olatoye, 2016; Situmorang, 2012; Umoru, 2015). Some other studies regarding the impact of new media have also been conducted (Neelamalar \& Chitra, 2009; Permatasari, Erlangga, Harlena, \& Chandra, 2013; Salman, Ibrahim, Abdullah, Mustaffa, \& Mahbob, 2011).

Like conventional mass media, new media also has a vital role in various fields, including in relation to democracy. In terms of the election as part of democracy practice, new media does not only support political parties or election candidates but also provides space for the public to be involved in the existing democratic process.

'Election selfie' has become a phenomenon that involves new media and the public in the current internet era. Although there is no mutual agreement yet between scientists to define the term, it has been happening along with the election itself. People 
take their photos by themselves with a pose that involves their finger, which has a stain of the ink from voting day. Therefore, some of the scientists use the term "inked finger selfie," and some others use "finger selfie." However, in this study, the phenomenon will be labeled as "inked finger selfie."

A selfie has become an acceptable word nowadays, since more people are using it, either in daily conversation or in academic discussion. Selfies refer to self-portraits taken by oneself using a digital camera or a smartphone and capture the photo independently without any helps from others (Qiu, Lu, Yang, Qu, \& Zhu, 2015). Having a selfie is challenging. It was required a unique art and technical skill, since selfie is done by people itself, without the favor from anyone else.

The popularity of selfies becomes greater and more significant with the increasing platform of social media, as a part of new media products. The social media has become the channel for them who have selfies to publish it. Not only because of the social media as the channel, but it also became more popular since the front camera became a standard feature of a smartphone.

Some studies related to this issue have been done, such as study in terms of selfie and personality expression (Qiu et al., 2015), the effect of selfie (Berg, 2018; Shin, Kim, Im, \& Chong, 2017), and also selfie pattern (Kurniawan, Habsari, \& Nurhaeni, 2017). Moreover, some articles about selfies as a trend in the current era also have been written by some researchers, such as Harisa who researched students' relationships with a selfie (Harisa, 2017). It was found that the students who did selfies tended to be a consumptive person in spending their money to purchase data packages for internet quota, supporting equipment for selfies, and the consumption of their smartphone. Based on the activities that follow the selfie among students in Harissa's article, it can be understood that selfie became a trend, especially a trend in a modern lifestyle that somehow requires more money in the fund spending.

Relating "inked finger selfie" during elections, it has started becoming a trend in Indonesia, since the 2014 presidential election. This phenomenon became a trending topic on Twitter, as reported by Tempo.Co online news (Tempo.co, 2014). It was reported that General Election Commission gave official comments regarding this phenomenon. The voters who gave the vote on April 19, 2014, posted their inked finger selfie on their Twitter account. Moreover, some companies got benefit from the trend by having some competitions, like Telkomsel with the contest "Go Vote, Selfie and Share," with one million prizes. In addition, in the regional head elections held in 2017, this phenomenon also reappeared. One of the polling stations in the city of Yogyakarta, even providing a special booth for voters to do selfies with inked fingers after they voted (Muhibar, 2017). Not only in Yogyakarta, a tourist destination management in Banyumas, Central Java Province also enlivened the democratic party by giving free tickets to their selfie photo booth if visitors were able to show evidence that they have used their right to vote (Anugrah, 2018).

In the latest simultaneous election held on April 17, 2019, a phenomenon related to inked selfies had become a trending topic on social media along with the online news publication. A famous Indonesian actor, Nicholas Saputra, with 1M Instagram followers (on May 20, 2019) uploaded an inked finger selfie photo on his Instagram account, (a) nicholassaputra, but he only kept the picture for 24 hours. This became viral because all this time, Nicholas Saputra's Instagram account had never displayed a picture of him. This made many online news sites raise it in the news, including online media that presents general news (Agnes, 2019; Billy, 2019; CNN_Team, 2019; Noviandi, 2019; 
Tiarasari, 2019; Zaenudin, 2019), not only entertainment news (Akmala, 2019; Futari, 2019; Safitri, 2019). Nicholas Saputra has been being a famous actor since his first debut as Rangga in "Ada Apa Dengan Cinta" movie that was released in 2002. His character as a cool and mysterious man while playing the role Rangga is still attached up to nowadays.

On the other hand, masculinity has been being an interesting concept in the research of media content, particularly in terms of it as a discourse. Defining masculinity is not an easy way. It can be viewed as a positive or a negative. It is positive when it is being seen as an identity signification for males, and it is negative when it is not the 'other' (feminine). Beynon, as cited in Itulua-Abumere (Itulua-Abumere, 2013) stated that masculinity and femininity are often treated in the media as opposites, with men typically assumed as a rational, practical, and naturally aggressive person. In contrast, women are typically expressive, nurturing, and emotional person.

Traditional masculinity involves the values of strength, power, fortitude, action, control, independence, autonomous, male partner friendship, and work. Barker and Galasinski as cited in Baker even mention that some values have no relation to traditional masculinity, such as relationships, ability in verbal things, domestic life, gentleness, communication, and also women and children (Baker, 2005).

The aforementioned phenomenon fosters a sense of curiosity of the researcher to study the masculinity represented from online news related to selfie photos taken by actor Nicholas Saputra, adopting Sara Mills's discourse analysis approach. Sara Mills is one of the outstanding figures in the study of critical discourse analysis. Sara Mills called the analysis she developed as Feminist Stylistics. Mills's discourse analysis model emphasizes how women are displayed in the text. Mills saw that so far women have always been marginalized in the text and always in the wrong position. In the text, they are not allowed to defend themselves. Therefore, this discourse model is often referred to as a feminist perspective discourse analysis (Fauzan, 2014).

Sara Mills also looked at how readers and writers are treated in the text, how the reader identifies and places himself in the narration of the text. This kind of position will put the reader in one position and influence how the text is displayed. In the end, the way of telling and positions placed and displayed in this text makes one party legitimized and the other party un-legitimized. According to Mills, as cited in Eriyanto, the concept of the position of the reader placed in the text was formed by the author not directly, but instead, this happened through reading in two ways, subject-object position, and writer-reader position (Eriyanto, 2011). Sara Mill's model of critical discourse analysis is adopted in this study to research about masculinity in the online news articles that report Nicholas post on Instagram regarding the election.

\section{Methodology}

This study employed critical discourse analysis, adopted Sara Mills' model, with subject-object position and writer-reader position as the stages of analysis. Data collection techniques employed in this study documented study, and sometimes it is called a literature study. A literature study is classified as a non-interactive collecting data method. It is a method of gathering data where the researcher collected data from verbal and written materials (Sutopo, 2006). In this research, documents used were varied from news articles from online news sites, journal articles, textbooks, reports, to survey results about new media, election, and selfie.

Twelve online news articles about inked finger selfie photos of Nicholas Saputra 
were popped when the researcher put the keyword "Nicholas Saputra selfie pemilu" (Nicholas Saputra election selfie) and limited the searching process by using a date filter, which is 17 April 2019, the voting day in Indonesia. However, not all of the news articles were used in this study. There were only five online news articles that considered as the data in this study because the Press Council of Indonesia factually and administratively verifies not all of the online news web sites found. Five news articles eligible for this study came from several verified online news web sites, which are suara.com, tribunnews.com, okezone.com, detik.com, and tirto.id.

The data will be analyzed using Sara Mills' critical discourse analysis, by looking at two aspects as follows: (1) subject-object position; it covers how events are seen, from whose perspective the events are seen. Who is positioned as the narrator (subject) and who positioned as the object that is being told. Whether each actor and social group have the opportunity to present themselves, ideas or their presence, the ideas are displayed by other groups or people, (2) writer-reader position; it covers what the location of the reader displayed by the author in the text is. How the reader positions himself in the text displayed. To which group the reader identifies himself (Eriyanto, 2011).

\section{Results and Discussion}

From the data collection and the data reduction process, five online news articles were selected as the object of this research, as presented in table 1.

Table 1. Data of online news article about Nicholas Saputra selfie in election 2019

\begin{tabular}{|c|c|c|c|}
\hline No & Date \& time & Title & Media \\
\hline 1. & $\begin{array}{l}\text { April 17, } 2019 \\
08.15 \mathrm{pm}\end{array}$ & $\begin{array}{l}\text { Foto Selfie Nicholas Saputra Bikin Heboh dan } \\
\text { Diikuti Selebriti Lain } \\
\text { [The selfie photo of Nicholas Saputra caused } \\
\text { excitement and was followed by other } \\
\text { celebrities] }\end{array}$ & suara.com \\
\hline 2. & $\begin{array}{l}\text { April 17, } 2019 \\
03.29 \mathrm{pm}\end{array}$ & $\begin{array}{l}\text { Gunakan Hak Pilih Pemilu 2019, Nicholas } \\
\text { Saputra Unggah 'Momen Langka' Foto Selfie di } \\
\text { Instagram } \\
\text { [Using } 2019 \text { Election Voting Rights, Nicholas } \\
\text { Saputra Uploads 'Rare Moments' of Selfie } \\
\text { Photos on Instagram] }\end{array}$ & $\begin{array}{l}\text { tribunpalu. } \\
\text { com }\end{array}$ \\
\hline 3. & $\begin{array}{l}\text { April 17, } 2019 \\
00.31 \mathrm{pm}\end{array}$ & $\begin{array}{l}\text { Nicholas Saputra Penuhi Janji Posting Foto } \\
\text { Selfie di Instagram saat Pemilu } \\
\text { [Nicholas Saputra Fulfills the Promise of Posting } \\
\text { Selfies on Instagram during the Election] }\end{array}$ & $\begin{array}{l}\text { okezone.c } \\
\text { om }\end{array}$ \\
\hline 4. & $\begin{array}{l}\text { April 17, } 2019 \\
01.11 \mathrm{pm}\end{array}$ & $\begin{array}{l}\text { Langka! Nicholas Saputra Pamer Foto Selfie } \\
\text { Setelah Nyoblos } \\
\text { [Rare! Nicholas Saputra Showing off Selfie } \\
\text { Photos after Voting] }\end{array}$ & detikinet \\
\hline 5. & April 17, 2019 & $\begin{array}{l}\text { Nicholas Saputra Selfie Usai Mencoblos, } \\
\text { Netizen Histeris } \\
\text { [Nicholas Saputra Selfie After voting, netizens } \\
\text { became hysterical] }\end{array}$ & tirto.id \\
\hline
\end{tabular}

(source: compiled by the researcher) 
Based on Sara Mills's model of cultural discourse analysis, she divided the analysis into two types, which are subject-object position and writer-reader position. Therefore, the discussion will be following the model. In the first part of the discussion, there will be an analysis of the subject-object position of five news articles as the object of the research. The analysis will be followed by the second part of Sara Mills's model, which is the writer-reader position.

\section{Subject-Object Position}

The five online news articles mentioned in general reported about the first selfie conducted by the Instagram account@nicholassaputra, in the context of the 2019 election. The photo showing actor Nicholas Saputra was showing his inked little finger was actually a campaign carried out to invite generations of people young to vote, and do not abstain. Regarding the subject-object position, it is crucial to find out how the events are seen. Nicholas Saputra's upload on his Instagram account is seen as new, strange, out of the ordinary, and rare. This can be seen in the following news on tribunpalu.com:

Nicholas Saputra is one of the few artists who display selfies or selfies on his social media. Not only on tribunpalu.com, on detikinet online news this issue appears from the following sentence:

The presence of Nicholas Saputra's selfie after voting also made it crowded. Crowded because a selfie photo of Nicholas Saputra is fairly rare. The moment of the 2019 election was even touted as the first time Nicholas showed off selfies at social media.

Furthermore, in the context of masculinity, this concept was raised in the form of traditional masculinity such as Baker's idea, one of which stated that masculinity is manifested in strength (Baker, 2005). In the context of the news about Nicholas Saputra's selfie, as an actor who had a lot of fans, he was seen as having the strengths to influence them, in terms of talking about this event. The news mentioned the number of fans who liked the upload and the number of Instagram users who gave comments. This is shown in the following news of tribunpalu.com:

Until this article was written, the upload of selfie photos of Nicholas Saputra on his Instagram account has received 238 thousand clicks on the Like button and 28.2 thousand comments.

It happens because, as an actor, he had several positive masculinity frameworks, which fit the work of Carlson \& Englar-Carlson as cited in Kiselica and Englar-Carlson. One of the positive masculinity frameworks they proposed that fit to this phenomenon is the humanitarian service of fraternal organizations (Kiselica \& Englar-Carlson, 2010).

The subject-object position also covers the perspective of the story. It is found that the story was told by the media itself, without the involvement of the actor itself. It can be seen from all of the online news articles that were the object of this research did not involve the quote or the direct comments from the object of the news. All of the news articles mostly only covered the phenomenon by adding some posts and comments from the Instagram account itself. It means that the object of the news did not have the privilege to defend himself so that he has to accept whatever the media told.

Because the object did not have the privilege to defend himself, so, generally, the 
narrator of this news was only the media, which includes the journalist, the editor, and editor-in-chief. The story was also mostly based on the value of the online news portal. There would be some differences in it despite only a slight of it. However, in the context of this phenomenon, the media can not be considered as the only narrator, because the news article source was mostly retrieved from the Instagram account along with the comments of the followers.

It is found in some news, such as in the article of suara.com as follows:

Enthusiastic about the photo of Nicholas Saputra, the citizen also requested that the photo not be deleted. The following comments regarding the selfie photo of Nicholas Saputra:

Dian Sastrowardoyo, an actress, commented on the post of the selfie.

Cheating.... Why does it only last in 24 hours, tong...!!!

In other online news articles, the materials also came from the Instagram account, like what is mentioned in tirto.id below:

Ira Rahmadhani, an Instagram user who commented on the Nicholas upload, said that the selfie photo "is the eighth wonder of the world.

Another user, Azarmila, said dude, how dare you only give me 24 hours.

Moreover, because the narrator is the media, so, the object of the news was the actor itself. From the online news articles that were being analyzed in this research, it can be seen that there was no balance in representing the context. Masculinity in this particular event was only represented by the media, and this representation would directly be consumed and understood by the audience, without knowing how the object wanted to be represented.

Masculinity is not only represented in terms of the strengths but also relates to the practical thinking that most men do. It is mentioned by Beynon as cited in Itulua-Abumere (Itulua-Abumere, 2013). The online news articles showed that Nicholas Saputra as a man that was so practical since no effort appeared in the news regarding the response of him answering the phenomenon that he causes in online life. By being practical, it can be seen that a man would take everything in a simple way, and he would stay away from something that is complicated.

\section{Writer-Reader Position}

In terms of writer-reader position, the analysis looked at how the position of the reader displayed by the author in the text. Not only that, from the perspective of the reader, it was also be needed to fond out how the reader positions himself in the text displayed, and to which group the reader identified him. However, in this work, the analysis will not cover the second part, because it only focused on how the online news portal places the audience regarding the message, and in this particular work, it relates to the concept of masculinity.

To analyze it, it is crucial to look at again the position of subject-object, because in this case, the object did not have the liberty to decide how he wanted to be pictured as a man. That way, the media held power to determine what is needed to be informed. In this case, the reader also had no place to have an opinion regarding anything that appeared in the news, including the masculinity.

Moreover, the sentences in the news were also only informative, and there was no 
choice for the reader to speak up about something they wanted to say. All of the objects of this study held a similar position in terms of giving room for the reader to have a thought on masculinity terms, including how they position. The reader did not have the liberty to place themselves in a particular position, either supporting the idea of masculinity or against it.

\section{Conclusion}

This paper has analyzed the representation of masculinity in online news, regarding the news about election selfie that was done by Nicholas Saputra, a well-known Indonesian actor with a plethora of followers in his Instagram account. It is concluded that in terms of subject-object position, the object of the news did not have a privilege to speak up on what he wanted to share, and in terms of masculinity, the traditional masculinity, especially the strengths, was represented in picturing the figure of Nicholas Saputra. In addition, as for the writer-reader position, the writer holds a more significant privilege to govern the reader's position, so that the reader can not have space also to give their opinions. This finding hopefully enriches the masculinity representation, especially in online media.

\section{References}

APJII, \& Polling-Indonesia. (2016). Infografis: Penetrasi \& Perilaku Pengguna Internet Indonesia (Survey 2016). Retrieved from https://apjii.or.id/content/read/39/264/Survei-Internet-APJII-2016

Baker, C. (2005). Cultural Studies: Theory and Practice. London: Sage Publications.

Barry, L., Cerf, V., David, C., Robert, K., Leonard, K., Daniel, L., ... Stephen, W. (2015). Brief History of the Internet. 1-17. Retrieved from https://www.internetsociety.org/wp-content/uploads/2017/09/ISOC-History-of-theInternet_1997.pdf

Berg, L. (2018). Young consumers in the digital era: The selfie effect. International Journal of Consumer Studies, 42(4), 379-388. https://doi.org/10.1111/ijcs.12431

Eriyanto. (2011). Analisis Wacana: Pengantar analisis teks media. Yogyakarta: LKiS.

Fauzan, U. (2014). Analisis Wacana Kritis dari Model Faiclough Hingga Mills. Jurnal Pendidik, 6(1).

Itulua-Abumere, F. (2013). Understanding Men and Masculinity in Modern Society. Open Journal of Social Science Research, 1(2), 42-45. https://doi.org/10.12966/ojssr.05.05.2013

Kemp, S. (2016). Digital in 2016: Global Overview - We Are Social UK. Retrieved from https://wearesocial.com/uk/blog/2017/01/digital-in-2017-global-overview

Kemp, S. (2017). Digital in 2017_ Global Overview - We Are Social.

Kemp, S. (2018). Digital in 2018: World's internet users. Retrieved from https://wearesocial.com/us/blog/2018/01/global-digital-report-2018

Kiselica, M. S., \& Englar-Carlson, M. (2010). Identifying, Affirming, and Building Upon Male Strenghts: The Positive Psychology/ Positive Masculinity Model of Psychotherapy with Boys and Men. Psychotherapy, 47(3), 276-287. https://doi.org/10.1037/a0021159

KPU_RI. (n.d.). Sejarah Pemilihan Umum Republik Indonesia. Retrieved from https://kpu.go.id/koleksigambar/1_OK___SEJARAH_PEMILU_1-5.pdf

Kurniawan, Y., Habsari, S. K., \& Nurhaeni, I. D. A. (2017). Selfie Culture: Investigating 
the Patterns and Various Expressions of Dangerous Selfies and the Possibility of Government's Intervention. The 2nd Journal of Government and Politics International Conference, II(July), 324-332.

Manovich, L. (2006). What is new media? In J. Hassan, Robert; Thomas (Ed.), The New Media Theory Reader (pp. 5-10). Retrieved from https://www.mheducation.co.uk/openup/chapters/0335217109.pdf

Neelamalar, M., \& Chitra, P. (2009). New media and society: A Study on the impact of social networking sites on indian youth. Estudos Em Communicacao N6, 125-145.

Olutola, A. T., Olatoye, O. O., \& Olatoye, R. A. (2016). Assessment of social mMedia utilization and study habit of students of tertiary institutions in Katsina State. Journal of Education and Practice, 7(3), 178-188. Retrieved from http://files.eric.ed.gov/fulltext/EJ1089804.pdf

Permatasari, H., Erlangga, D., Harlena, S., \& Chandra, R. (2013). Effect of Social Media on Website Popularity. Doaj.Org, 3(2), 32-37. Retrieved from http://www.doaj.org/doaj?func=fulltext\&aId=1301696

Qiu, L., Lu, J., Yang, S., Qu, W., \& Zhu, T. (2015). What does your selfie say about you? Computers in Human Behavior, 52, 443-449. https://doi.org/10.1016/j.chb.2015.06.032

Salman, A., Ibrahim, F., Abdullah, M. Y., Mustaffa, N., \& Mahbob, M. H. (2011). The impact of new media on traditional mainstream mass media. Innovation Journal, 16(3), 2-11. https://doi.org/10.5829/idosi.mejsr.2014.22.04.21945

Shin, Y., Kim, M., Im, C., \& Chong, S. C. (2017). Selfie and self: The effect of selfies on self-esteem and social sensitivity. Personality and Individual Differences, 111, 139145. https://doi.org/10.1016/j.paid.2017.02.004

Situmorang, J. R. (2012). Pemanfaatan Internet Sebagai New Media Dalam Bidang Politik , Bisnis , Pendidikan Dan Sosial Budaya. Jurnal Administrasi Bisnis, 8(1), 73-87. https://doi.org/10.1109/ICPP.2011.45

Sutopo, H. B. (2006). Metodologi Penelitian Kualitatif: Dasar Teori dan Terapannya dalam Penelitian. https://doi.org/10.1192/bjp.205.1.76a

Teknopreneur, A. (2017). Infografis: Penetrasi \& Perilaku Pengguna Internet Indonesia - Survey 2017. 2018(31 August 2018), Hasil Survey.

Umoru, T. A. (2015). Challenges and Opportunities of Utilization of Social Media by Business Education Students in Nigeria Universities. International Scholarly and Scientific Research \& Innovation, 9(11), 3616-3620. 